\title{
Spatial differences in larval abundance within the coastal boundary layer impact supply to shoreline habitats
}

\author{
Kerry J. Nickols ${ }^{1,4, *}$, Seth H. Miller ${ }^{1}$, Brian Gaylord ${ }^{1,2}$, Steven G. Morgan $^{1,3}$, \\ John L. Largier ${ }^{1,3}$ \\ ${ }^{1}$ Bodega Marine Laboratory, University of California at Davis, Bodega Bay, California 94923, USA \\ ${ }^{2}$ Department of Evolution and Ecology, University of California at Davis, Davis, California 95616, USA \\ ${ }^{3}$ Department of Environmental Science and Policy, University of California at Davis, Davis, California 95616, USA \\ ${ }^{4}$ Present address: Hopkins Marine Station, Stanford University, Pacific Grove, California 93950, USA
}

\begin{abstract}
Explorations of the dynamics of nearshore regions of the coastal zone are missing from many efforts to understand larval transport and delivery to suitable habitats. Larval distributions in the coastal ocean are variable and depend on physical processes and larval behaviors, leading to biophysical interactions that may increase larval retention nearshore and bolster their return to natal sites. While recent evidence suggests that many larvae are retained within a few kilometers from shore, few studies incorporate measurements sufficiently close to shore to plausibly assess supply to the shoreline benthos. We measured cross-shore distributions of larvae of benthic crustaceans between 250 and $1100 \mathrm{~m}$ from shore (i.e. just beyond the surf zone) within the coastal boundary layer (CBL) - a region of reduced alongshore flow - and simultaneously quantified a suite of physical factors that may influence larval distributions. We found high larval abundance within the CBL, with a peak at $850 \mathrm{~m}$ from shore, and a decrease in abundance along the shoreward edge of the sampled transect. We also found distinctly different larval assemblages at outer stations within the CBL, as compared to inner stations that are more influenced by shoreline dynamics. These patterns persisted across sample dates, suggesting that the spatial structure of nearshore larval assemblages is at least somewhat robust to temporal changes in physical conditions. Thus, while larval abundance appears to be high within the CBL, larvae appear to be sparse within the narrow band of water adjacent to the surf zone. Low larval supply adjacent to suitable habitats has important implications for the coupling of supply and recruitment, and resulting dynamics of shoreline populations.
\end{abstract}

KEY WORDS: Dispersal $\cdot$ Invertebrate larvae $\cdot$ Retention $\cdot$ Nearshore $\cdot$ Transport

\section{INTRODUCTION}

A central goal of ecology is to understand patterns of abundance and distribution of organisms. Determining the key factors that drive population dynamics requires knowledge of demographic inputs (birth and immigration) and losses (death and emigration). In marine systems, the process of larval dispersal adds additional complexity to quantifying population inputs as many marine organisms release dispersive larvae that act as the primary agents coupling birth at one site to immigration at another. Therefore, larval recruitment to coastal populations relies not only on reproductive output of parent populations and postsettlement processes, but also on oceanographic factors that affect the dispersal and delivery of settlers 
(Cowen 1985, Gaines et al. 1985, Roughgarden et al. 1988, Gaylord \& Gaines 2000, Morgan 2001, Underwood \& Keough 2001, Largier 2003, Prairie et al. 2012). While larval recruitment is a critical determinant of population structure (Gaines \& Roughgarden 1985, Underwood \& Fairweather 1989, Menge et al. 2004) and larval delivery has long been recognized for its role in driving population dynamics (Thorson 1946), larval transport pathways and connectivity are difficult to quantify due to the small size of larvae and the difficulty of tracking them (Levin 2006). These difficulties are exacerbated by a lack of understanding of how larval supply varies over time and space.

Relatively few studies have measured larval supply and settlement concurrently in such a way as to explicitly link them. Those that have done so have reached mixed conclusions: some found supply and settlement to be coupled (e.g. Gaines et al. 1985, Bertness et al. 1992, Gaines \& Bertness 1992, Dudas et al. 2009) while others did not (e.g. Yoshioka 1982, McCulloch \& Shanks 2003, Rilov et al. 2008). Such differences may be due to the magnitude of recruitment, with larval supply acting as a strong predictor of adult dynamics in regions where recruitment is limited (Connell 1985), but less so in areas where recruitment is high. Connections between supply and settlement or recruitment may be easier to assess in other systems; for instance those involving dispersal of macroalgal spores (see, e.g. Reed et al. 1988, Gaylord et al. 2002, 2004, 2006, 2012, Reed et al. 2006).

Much of the west coast of North America is recruitment-limited to one degree or another, such that larval supply is a critical determinant of population dynamics in many species. This feature derives from the fact that the west coast sits within a major upwelling region. During times of strong equatorward winds, the predominant currents flow equatorward and surface waters move offshore. The potential for upwelling waters to move larvae offshore has been widely recognized (Yoshioka 1982, Roughgarden et al. 1988, Botsford et al. 1994), and is consistent with observations that larval settlement and supply in persistent upwelling regions is higher during relaxation events when wind speeds decrease or reverse directions (Farrell et al. 1991, Botsford 2001). Increases in settlement and supply during relaxation events can also result from poleward advection of larvae (Wing et al. 1995a,b). More recent work has shown the persistence of sequential larval stages in nearshore plankton during upwelling conditions, indicating that many taxa are not swept offshore in upwelling regions (Morgan et al. 2009b, Shanks \& Shearman 2009). Larvae appear to be able to at least partially avoid offshore transport associated with upwelling through physical and behavioral mechanisms. Nearshore retention zones arising from topographic effects on coastal circulation have been observed (Graham \& Largier 1997, Wing et al. 1998, Roughan et al. 2005), and are associated with higher larval abundances and settlement (Mace \& Morgan 2006, Morgan et al. 2009a, 2011, 2012). Avoidance of surface waters by larvae can favor retention and decrease offshore transport (Morgan et al. 2009b,c, Shanks \& Shearman 2009, Morgan \& Fisher 2010, Morgan et al. 2012) and there is mounting evidence that larval concentrations are high close to shore, even in areas of strong upwelling that are traditionally viewed as being recruitment-limited. Here we investigate this phenomenon closer to shore to see if high abundances extend over the inner shelf and inward to the shoreline.

Nearshore processes play an important role in larval ecology, and may be relevant for a significant portion of pelagic larval durations. A number of recent studies measured larval abundance in crossshore transects and found increases in abundance closer to shore in a range of invertebrates and fishes (Borges et al. 2007, Tapia \& Pineda 2007, Morgan et al. 2009b,c, Shanks \& Shearman 2009). For example, Morgan et al. (2009b) measured larval abundance of benthic crustaceans from $1 \mathrm{~km}$ from shore out to the shelf break (30 km offshore) along the open coast of northern California and found that the highest larval abundances were within $3 \mathrm{~km}$ from shore. The combination of larval behaviors (e.g. swimming and vertical migration) and nearshore processes may increase retention of larvae close to shore and to their natal site. Such retention is consistent with evidence from a range of species and systems that shows selfrecruitment is higher and dispersal distances smaller than previously thought (Swearer et al. 2002, Levin 2006, Shanks 2009), and further emphasizes the importance of understanding the role of nearshore processes in larval supply and population dynamics.

A number of nearshore processes may reduce scales of dispersal. Adjacent to the shore within the surf zone, rip tides can create recirculation zones (MacMahan et al. 2010) and onshore wave transport can lead to accumulation of water-borne material (Monismith 2004, McPhee-Shaw et al. 2011). There is also a region termed the coastal boundary layer (CBL) that extends beyond the surf zone and is characterized by reduced speeds (Nickols et al. 2012). In particular, average alongshore velocities in the CBL are an order of magnitude larger than cross-shore velocities (Lentz et al. 1999, Gaylord et al. 2007), and 
alongshore velocities increase strongly with distance from shore until reaching a 'free-stream' value offshore (Nickols et al. 2012). Such decreased velocities provide another potential mechanism for reducing scales of dispersal in coastal populations (Nickols et al. 2012, Nickols et al. unpubl. data), but require that larvae spend sufficient time within the CBL for reduced flow to influence net transport. Because previous studies of coastal larval distributions did not extend into the CBL or only just entered the CBL (McQuaid \& Phillips 2000, Morgan et al. 2009b,c, Shanks \& Shearman 2009), or sampled over an insufficient temporal scale to fully characterize patterns (Tapia \& Pineda 2007), the general role of the CBL in influencing patterns of larval transport and supply remains unknown.

The goals of this study were therefore to address the following questions: (1) what is the spatial pattern of larval abundance within the CBL, (2) are there differences in larval assemblages close to shore (i.e. are different larvae found inshore versus offshore within the CBL), and (3) do time-dependent or spacedependent physical processes tend to dictate variability in larval abundance? We recognize in targeting these goals that it is not possible to definitively ascribe particular mechanisms to observed patterns; rather, our aim is to present the first description of the spatio-temporal distribution of larval assemblages

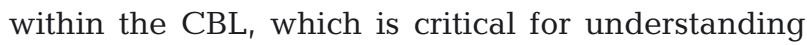
the potential for nearshore transport processes to impact larval supply to shoreline habitats. We additionally hope that this study will also inform the methodological question of where supply should be measured to best address relationships between settlement and supply when exploring questions about marine population dynamics, particularly for recruitment-limited regions.

\section{MATERIALS AND METHODS}

\section{Study system and species}

This study was conducted along the open coast in northern California, USA, near Bodega Head, California (Fig. 1), a region characterized by strong seasonal upwelling during spring and summer that drives prevailing currents equatorward and pushes surface waters offshore (Winant et al. 1987, Largier et al. 1993). When the winds weaken or reverse direction (inducing a 'relaxation' event), currents move poleward, often responding within a day or less in very nearshore regions (Send et al. 1987). Inner shelf

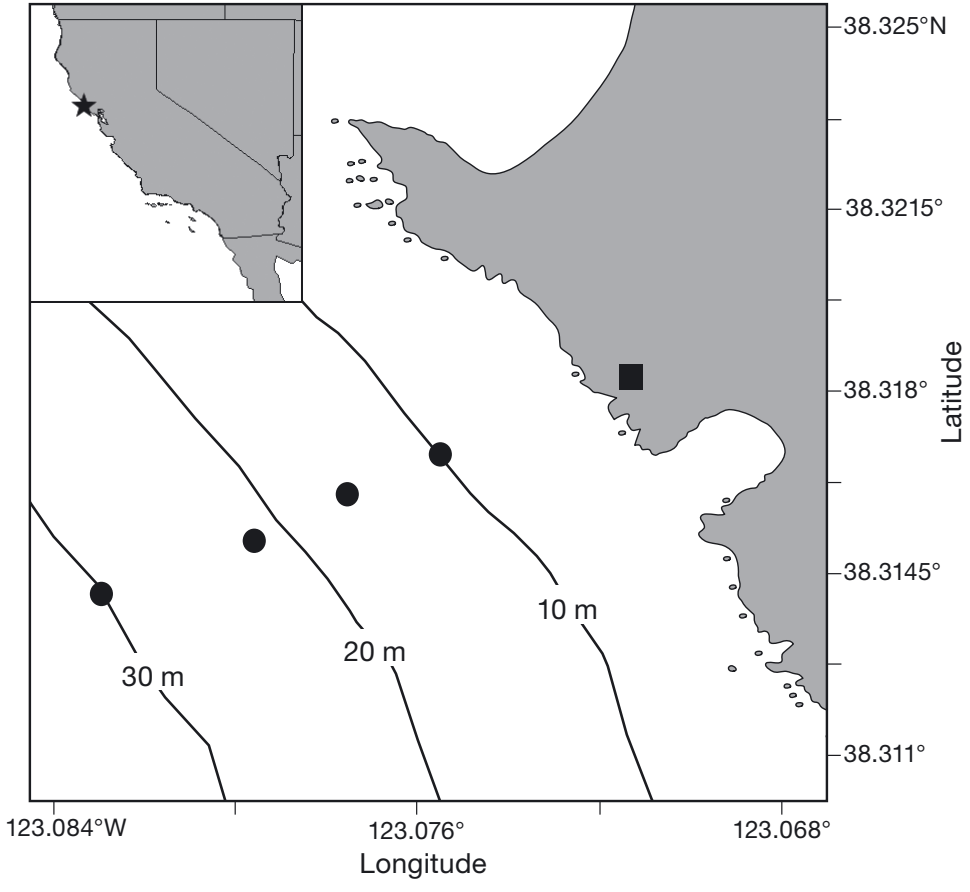

Fig. 1. Map of the study region showing the cross-shelf transect located off Bodega Head in northern California, USA. Circles indicate locations of moorings where plankton tows and CTD casts began. The moorings on the 10, 15, and $22 \mathrm{~m}$ isobaths included bottom mounted ADCPs and thermistors. The mooring on the $15 \mathrm{~m}$ isobath contained a thermistor string measuring temperature at depths of $4,7,10$, and $14 \mathrm{~m}$. Wind velocity was measured via an anemometer located onshore at the Bodega Marine Laboratory, indicated by the square

currents, observed previously on the scale of kilometers, are slower than currents farther offshore, have a higher tendency to move poleward (Kaplan et al. 2005), and are associated with increases in invertebrate settlement (Wing et al. 1995a,b). Benthic crustacean larvae can be present during both relaxation and upwelling conditions within areas of topographic retention and along the open coast, and many can be retained in areas within 1 to $3 \mathrm{~km}$ of the shore via a combination of physical and behavioral mechanisms (Morgan et al. 2009b, Morgan \& Fisher 2010, Morgan et al. 2012). The present study focused on waters within $1 \mathrm{~km}$ of the shore.

Our efforts focused on larvae of benthic crustaceans (primarily barnacles and crabs), which are the best-studied meroplankton in this region. From prior work, it is known that larval abundance of benthic crustaceans peaks during the spring and summer, coinciding with the upwelling season. Barnacles molt through 6 larval stages (nauplii) and a postlarval stage (cyprid) and spend about 2 to $4 \mathrm{wk}$ in the water 
column (Strathmann 1987). Barnacle larval release generally begins in spring (Gaines et al. 1985, Strathmann 1987) and is continuous through the summer months (Shanks \& Eckert 2005). Barnacle species from both subtidal (Balanus crenatus, B. nubilus) and intertidal (B. glandula, Chthamalus spp., and Pollicipes polymerus) habitats are common in this region (Morgan \& Fisher 2010). Crab larvae spend weeks to months in the plankton, and peak recruitment for most species in this region is during the spring and summer (Shanks \& Eckert 2005, Mace \& Morgan 2006). The most common taxa include members of the families Pinnotheridae, Porcellanidae, Cancridae, and Majidae.

\section{Larval samples}

Cross-shore distributions of nearshore larvae were sampled during 6 daytime cruises using a $0.5 \mathrm{~m}$ diameter, $200 \mu \mathrm{m}$ mesh net equipped with a mechanical flow meter (Model 2030, General Oceanics). The net was modified with a sled to accommodate towing along the bottom. Cruise dates spanned 3 mo during the upwelling season, from May through July 2010, and occurred approximately every $10 \mathrm{~d}$ (Fig. 2) under a variety of oceanographic conditions. We sampled 4 stations in a cross-shore transect along the 10, 15, 22, and $30 \mathrm{~m}$ isobaths, corresponding to approximately 250,425, 850, and $1100 \mathrm{~m}$ from shore (Fig. 1). We refer to the 10 and $15 \mathrm{~m}$ isobath stations as 'inner CBL stations', and the 22 and $30 \mathrm{~m}$ isobath stations as 'outer CBL stations'. We conducted a single $10 \mathrm{~min}$ oblique tow at each station, which sampled from the bottom to the surface of the water column. Larvae were sorted and identified to species, or the lowest taxonomic group possible, and developmental stage. Larval abundances were calculated per $\mathrm{m}^{3}$ to standardize across stations.

\section{Physical data}

To provide physical context during our study, we measured currents, temperature, salinity, and winds. Current speed and direction were measured throughout the water column using moored acoustic Doppler current profilers (Workhorse Sentinel ADCP, 1200 $\mathrm{kHz}$; Teledyne RD Instruments). Instruments were located on the 10,15 , and $22 \mathrm{~m}$ isobaths near the starting position for plankton tows. The ADCPs collected 1 min bursts of $0.75 \mathrm{~Hz}$ velocity data every 2 min in $1 \mathrm{~m}$ vertical bins that typically extended from $\sim 1.5 \mathrm{~m}$ above the bottom to $\sim 1.5 \mathrm{~m}$ below the surface. The velocity record at the $10 \mathrm{~m}$ station ended early on 10 June 2012 when its anchor was dislodged. To quantify general velocity patterns, the raw velocity time series were depth-averaged, rotated onto their principal axes, and low-pass filtered with a $33 \mathrm{~h}$ cutoff to remove dominant tidal motions (Rosenfeld 1983). The major principal axes aligned parallel to shore and along-isobath, corresponding to an angle of $300^{\circ}$.

Bottom temperature was recorded at the ADCP mooring sites every minute over the duration of the study at the 10, 15, and $22 \mathrm{~m}$ stations, and temperatures at depths of $4,7,10$, and $14 \mathrm{~m}$ were recorded at the $15 \mathrm{~m}$ station (SBE 37 and SBE 39, Sea-Bird Electronics). During cruises, temperature, salinity, and density were profiled at each station throughout the water column using a conductivity, temperature, and depth profiler (SBE 19-Plus, Sea-Bird Electronics), with the exception of the cruise on 25 June.

Wind data during this study were available from an anemometer located on the shore at the Bodega Marine Laboratory, within $1 \mathrm{~km}$ of the study locations, at a height of $20 \mathrm{~m}\left(38^{\circ} 19^{\prime} 3.35^{\prime \prime} \mathrm{N}, 123^{\circ} 4^{\prime} 17.20^{\prime \prime} \mathrm{W}\right.$; RM Young 05103 Wind Monitor; data available online http://bml.ucdavis.edu/boon/).

\section{Data analysis}

We performed multivariate analyses to determine if larval abundance and larval assemblages varied with distance from shore and with time. We examined patterns of cross-shore abundance for all taxa, for crab and barnacle larvae separately, and according to larval stage. All statistical analyses were conducted using the multivariate statistical software package PRIMER v. 6.1.10 (Clarke \& Gorley 2006). We determined whether larval assemblages changed with distance from shore and with sampling date using nonparametric analysis of similarity (ANOSIM) and hierarchical cluster analysis and ordination. Data were fourth-root transformed to reduce the heterogeneity of variance among samples and assembled into a Bray-Curtis dissimilarity matrix with a dummy variable of 1 . The resultant dendrogram was tested for group differences using a similarity profile test (SIMPROF), and the percentage contribution (SIMPER) of each species and stage to the significant clusters was assessed to classify species-stage combinations by their cross-shore distributions and sampling date. We used non-metric multidimensional scaling 

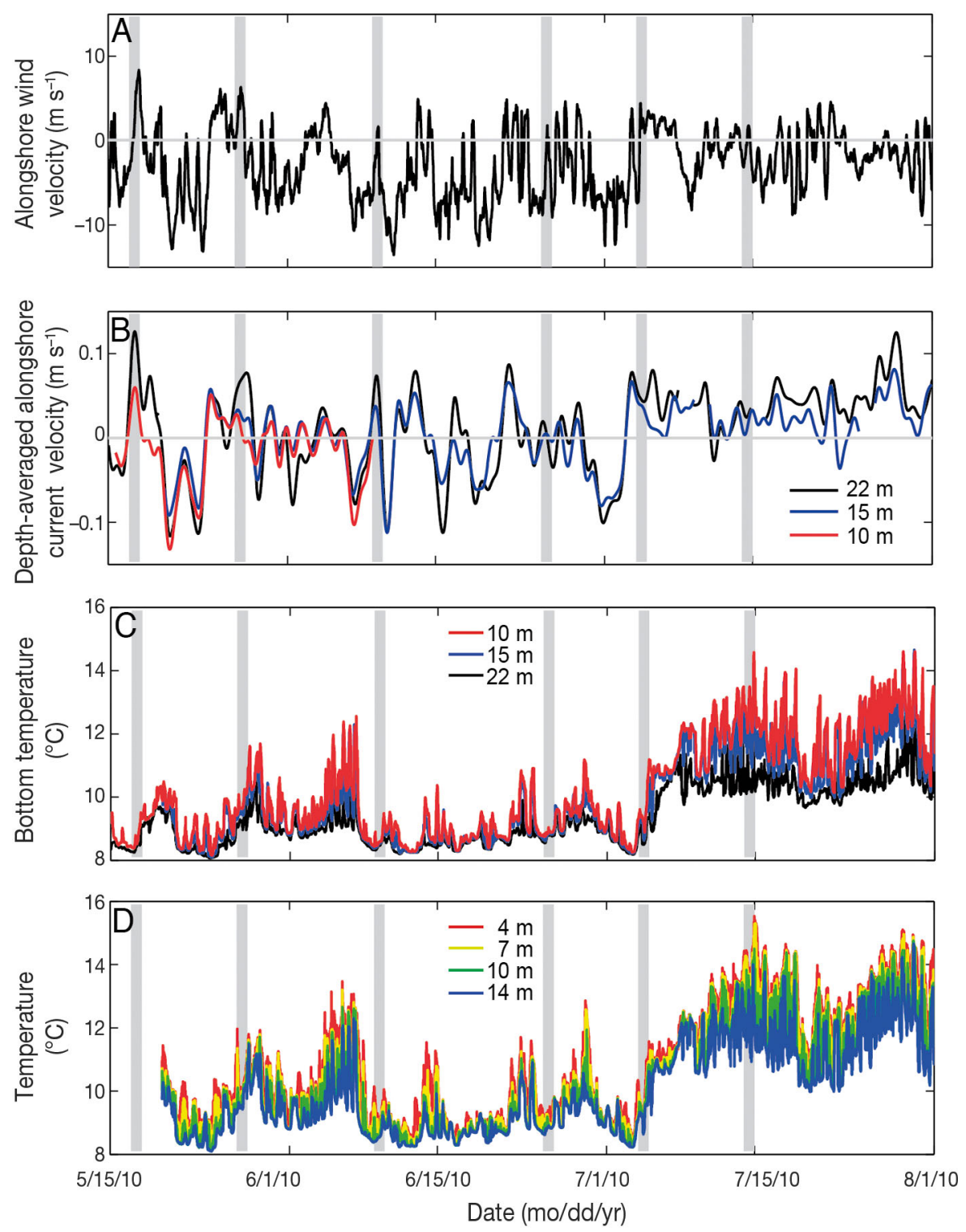

Fig. 2. (A) Alongshore wind velocity measured at Bodega Marine Laboratory. (B) Alongshore depth-averaged and $33 \mathrm{~h}$ low-pass filtered current velocity measured by bottom-moored ADCPs at the 10, 15, and $22 \mathrm{~m}$ isobaths. Positive alongshore velocity is poleward and negative alongshore velocity is equatorward. (C) Bottom temperature measured on the ADCP moorings at the 10, 15, and $22 \mathrm{~m}$ isobaths. (D) Temperature at depths of 4, 7, 10, and $14 \mathrm{~m}$ measured at the $15 \mathrm{~m}$ isobath. Vertical gray bars indicate when sampling occurred

\section{RESULTS}

\section{Physical conditions}

During the study period, we captured a variety of oceanographic conditions, including upwelling, relaxation, and post-relaxation (Fig. 2). However, our larval sampling dates generally occurred during low-wind conditions due to logistical constraints on field operations. Daily-averaged alongshore wind speeds during each sampling date ranged from $-8 \mathrm{~m} \mathrm{~s}^{-1}$, indicative of northwesterly winds, to $8 \mathrm{~m} \mathrm{~s}^{-1}$, indicative of southeasterly winds, but winds were predominantly upwelling favorable over the study period (Fig. 2A). While depth-averaged alongshore currents are known to alternate between equatorward and poleward in this region (Largier et al. 1993, Roughan et al. 2005, Kaplan \& Largier 2006, Morgan et al. 2012), on all sampling days of our study the alongshore current was poleward (Fig. 2B). In general, depthaveraged alongshore velocities measured at inner CBL locations (10 and $15 \mathrm{~m}$ isobaths) were slower than velocities measured at the outer CBL instrument on the $22 \mathrm{~m}$ isobath (Fig. 2B), characteristic of a coastal boundary layer. Exceptions occurred during onset of strong upwelling winds on 20 May and 6 June and during flow reversals.

Water column properties during larval sampling dates ranged from well-mixed to stratified (Figs. 2 \& 3). The 17 May, 9 June, and 25 June sampling events represented upwelling conditions, with a cold homogeneous water column across sta-

(NMDS) to examine separation of assemblages according to sample date and distance from shore. To assess if community composition was structured in space or time, we repeated each of these analyses on untransformed data that were standardized by total sample abundance. For all analyses, when there was significant structure among samples we then determined which species and stages contributed to the patterns. tions: temperatures below $10^{\circ} \mathrm{C}$ and salinities similarly uniform, with the exception of some lowsalinity water on the surface near the outer station on 17 May (Figs. 2, 3A \& 3C). Alongshore wind speeds on the day preceding these sampling dates were from the northwest and reached up to $10 \mathrm{~m} \mathrm{~s}^{-1}$, characteristic of strong upwelling conditions and accounting for the presence of cold isothermal conditions over the inner shelf. On 27 May and 4 July, the 

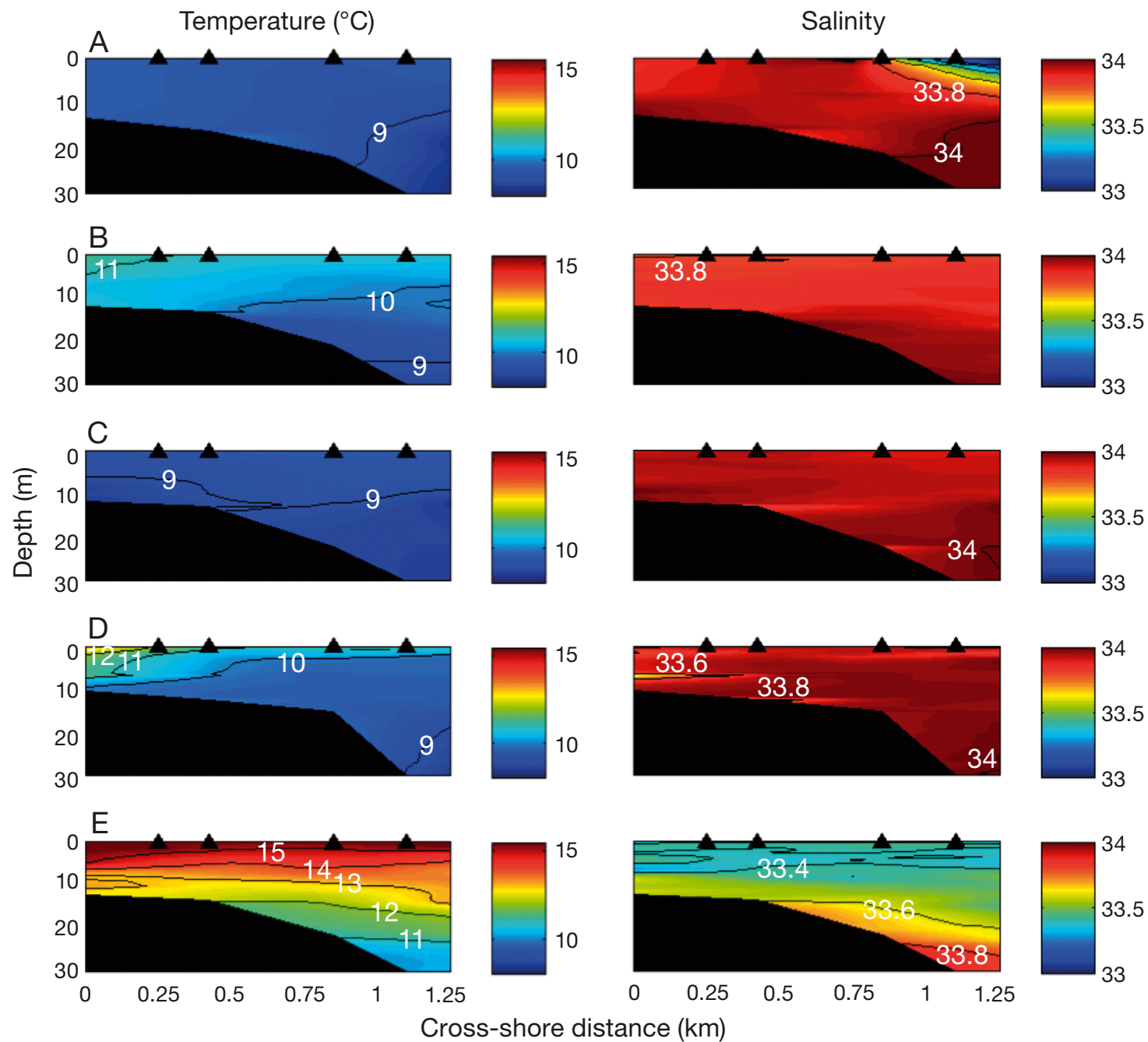

Fig. 3. Contours of temperature (left) and salinity (right) at the beginning of larval tows along the 10, 15, 22, and 30 m isobaths on (A) 17 May 2010, (B) 27 May 2010, (C) 9 June 2010, (D) 4 July 2010, and (E) 14 July 2010. Sample locations are indicated by triangles

water column was stratified at the 2 inner CBL stations (Figs. 2, 3B \& 3D), following a day of southeasterly or weak winds. After 4 July temperatures increased substantially, and the water column was stratified at all stations on the 14 July sampling day (Fig. 2C). Winds during this period were substantially weaker than previous sampling events (Figs. 2C, 2D \& $3 \mathrm{E})$.

\section{Larval abundance}

We identified larvae of 22 crustacean species during our study (Table 1). The outer CBL station, along the $30 \mathrm{~m}$ isobath, had the highest number of species, with 10 species on average as compared to 6 to 7 spe- cies at the other stations. Throughout the study, larvae were most abundant along the $22 \mathrm{~m}$ isobath, $850 \mathrm{~m}$ from shore (Fig. 4A). This pattern was driven by high abundances of barnacle larvae (Fig. 4B). Early, middle and late stage barnacle larvae were present at all stations with the highest abundance along the $22 \mathrm{~m}$ isobath (Fig. 5A). Barnacle postlarvae (cyprids) were found in similar abundance across stations. Crab larvae were most abundant near the $30 \mathrm{~m}$ isobath, $1100 \mathrm{~m}$ from shore (Fig. 4C). All larval crab stages were most abundant at the 2 outer CBL stations, although early stage crab larvae dominated the samples and abundance decreased with increasing stage (Fig. 5B). Very few crab larvae were found at the inner CBL stations, and the majority of those were early stage larvae. 
Table 1. Crustacean larvae identified in the study

\begin{tabular}{|ll|}
\hline Family & Taxon \\
\hline Cirripedia & Balanus crenatus \\
& Balanus glandula \\
& Balanus nubilus \\
& Chthamalus dalli \\
& Pepas spp. \\
Cancridipes polymerus & Cancer antennarius \\
& Cancer magister \\
& Cancer productus \\
Grapsidae & Carcinus maenas \\
Hippidae & Hemigrapsus oregonensis \\
Majidae & Emerita analoga \\
& Mimulus foliatus \\
& Pugettia producta \\
Paguroidae & Pugettia richii \\
Pinnotheridae & Scyra acutifrons \\
Porcellanidae & Pagurid spp. \\
Thalassinidae & Pinnotheridae \\
Xanthidae & Pachycheles spp. \\
& Petrolisthes cinctipes \\
& Neotrypaea californiensis \\
& Lophopanopeus bellus \\
\hline
\end{tabular}

\section{Larval assemblages}

Considering all taxa, larval assemblages within the CBL differed among stations (2-way ANOSIM $\rho_{\mathrm{av}}=$ $0.322, \mathrm{p}=0.017$ ) and were similar among dates. Because overall larval assemblages were not structured by date we performed a 1-way ANOSIM to detect spatial differences among assemblages at the different stations. The innermost station drove differences between assemblages, and it differed from the 2 outer stations (1-way ANOSIM pairwise test: for $10 \mathrm{~m}$ vs. $30 \mathrm{~m}$ stations: $R=0.463, \mathrm{p}<0.01$; for $10 \mathrm{~m}$ vs. $22 \mathrm{~m}$ stations: $R=0.609, \mathrm{p}<0.01)$. These differences were echoed in the dendrogram from cluster analysis, and the NMDS ordination, which both revealed spatial structure with 2 main clusters: one defined by low numbers of larvae, with samples primarily from inner CBL stations, and the second defined by high numbers of larvae, with samples primarily from the outer CBL stations (Fig. 6).

Partitioning the analysis by taxa, we found that patterns of barnacles and crabs differed. Crab larval assemblages by themselves did not differ by station or date, but barnacle larval assemblages did differ by station and sampling date (2-way ANOSIM: station $\rho_{\mathrm{av}}=0.322, \mathrm{p}=0.02$; date $\left.\rho_{\mathrm{av}}=0.35, \mathrm{p}<0.01\right)$. The dendrogram from cluster analysis and the NMDS ordination revealed 2 main clusters of barnacle samples. One cluster occurred early in the season and mostly offshore, and it was composed of samples from all stations during 17 May and samples from the outer CBL stations during June and July. The other cluster occurred late in the season (June through July) and consisted primarily of samples from the inner CBL stations (Fig. 7). In the early-season, outer CBL assemblage, barnacle larval abundances were as high as 7200 larvae $\mathrm{m}^{-3}$, whereas in the lateseason, inner CBL assemblage, barnacle concentrations were less than 500 larvae $\mathrm{m}^{-3}$.

We also analyzed changes in the composition of the larval assemblage. We divided our larval counts (both species and stage) by the total number of larvae in each sample, providing a fraction of the total sample for each species and stage, to standardize the data for differences in larval abundance across time. Larval community composition within the CBL differed mostly among stations, but also by date (2-way ANOSIM station $\rho_{\mathrm{av}}=0.394, \mathrm{p}<0.01$; date $\rho_{\mathrm{av}}=0.282$, $\mathrm{p}=0.026)$. As noted previously, date was not significant when abundance was considered in the analysis of larval assemblages. In this analysis of composition,
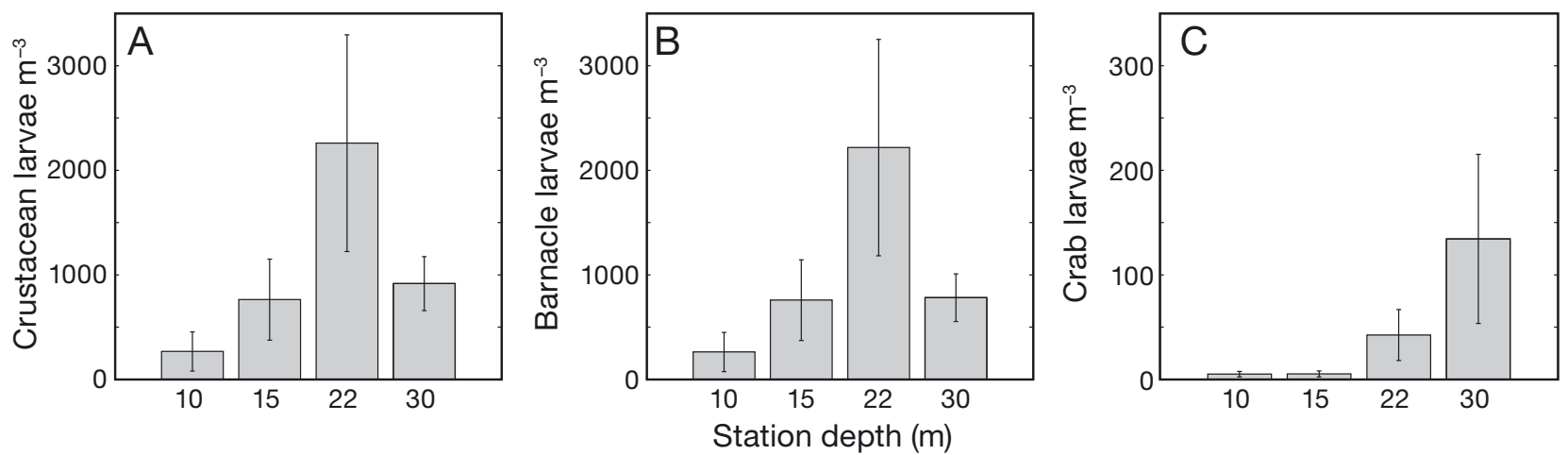

Fig. 4. Average larval abundance and standard error across date by station for (A) all benthic crustaceans, (B) barnacles, and (C) crabs. Note that the $y$-axis of $(C)$ is an order of magnitude smaller than (A) and (B) 


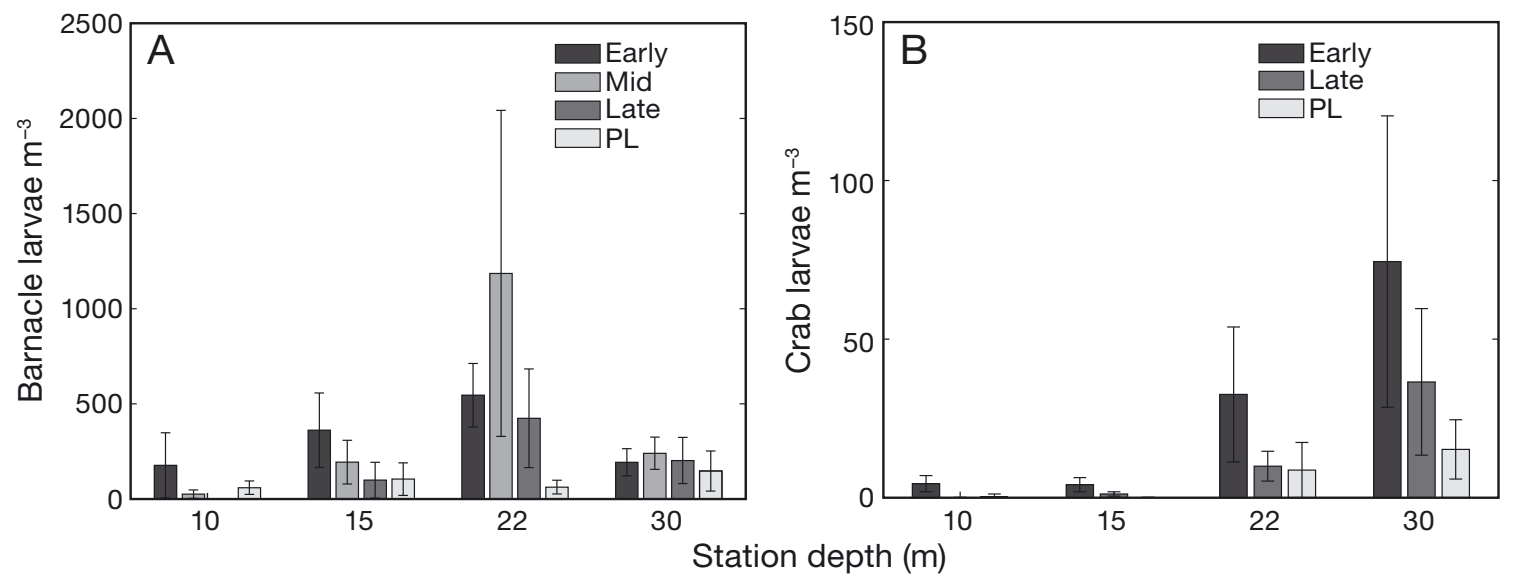

Fig. 5. Average larval abundance and standard error across date by station for (A) barnacles according to early, mid, late, and postlarval (PL) stage and (B) crabs according to early, late, and PL stage
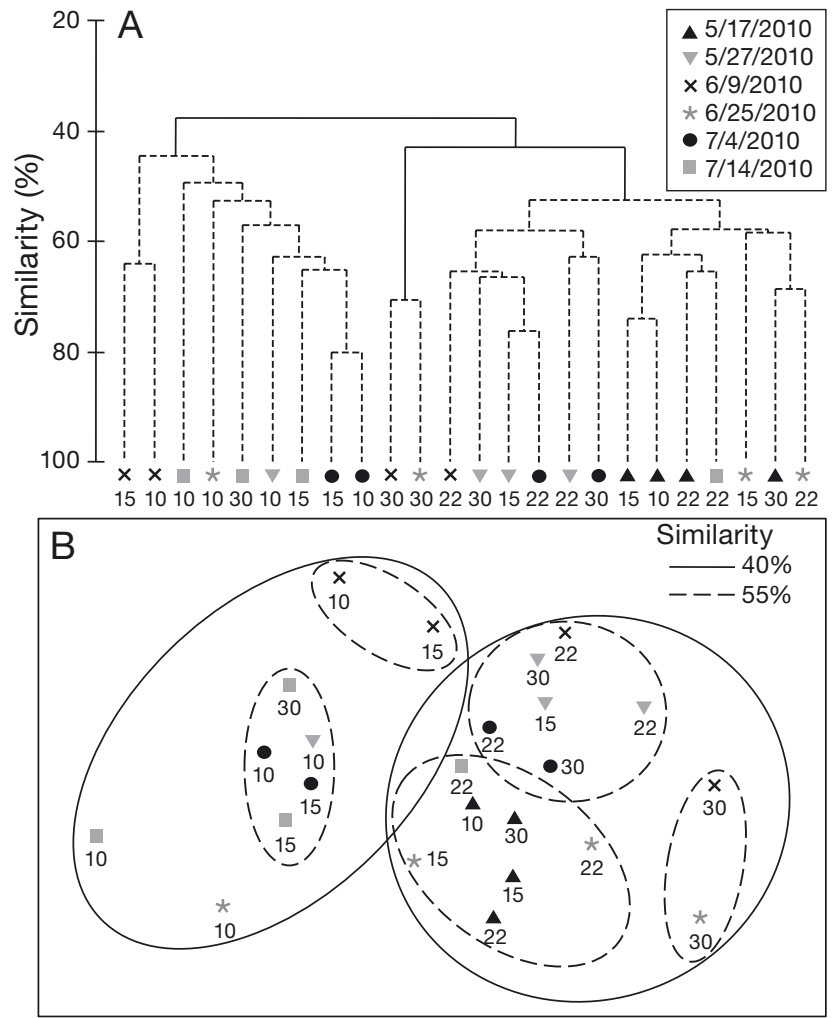

Fig. 6. (A) Hierarchical clustering dendrogram (using groupaverage linking) of larval assemblages of benthic crustaceans from 24 samples taken over 6 d (indicated by symbols and legend entry) at 4 sampling stations across the coastal boundary layer (along the 10, 15, 22, and $30 \mathrm{~m}$ isobaths, indicated by numbers adjacent to symbols), using transformed data. Solid black lines indicate significant group structure at the $5 \%$ level. Dashed lines represent nonsignificant group structure. Sample station isobaths are reported beneath each symbol. (B) Non-metric multidimensional scaling plot (2D stress, $0.15 ; 3 \mathrm{D}$ stress, 0.09 ) from the 24 samples with superimposed significant clusters at similarity levels of $40 \%$ (solid lines) and $55 \%$ (dashed lines). Symbols and numbers as in (A)
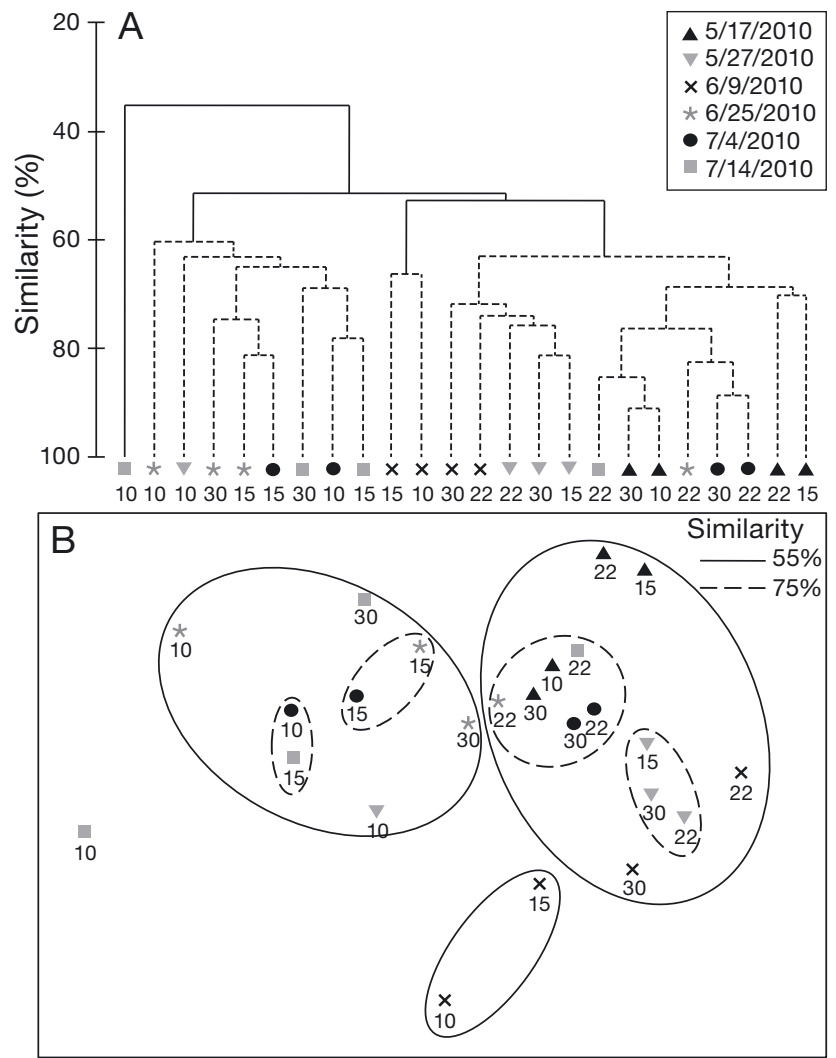

Fig. 7. (A) Hierarchical clustering dendrogram (using groupaverage linking) of barnacle larval assemblages from 24 samples taken over $6 \mathrm{~d}$ (indicated by symbols and legend entry) at 4 sampling stations across the coastal boundary layer (along the 10, 15,22, and $30 \mathrm{~m}$ isobaths, indicated by numbers adjacent to symbols). Solid black lines indicate significant group structure at the $5 \%$ level. Dashed lines represent non-significant group structure. Sample station isobaths are reported beneath each symbol. (B) Non-metric multidimensional scaling plot (2D stress, 0.12 ; 3D stress, 0.07 ) from the 24 samples with superimposed significant clusters at similarity levels of $55 \%$ (solid lines) and $75 \%$ (dashed lines). Symbols and numbers as in (A) 


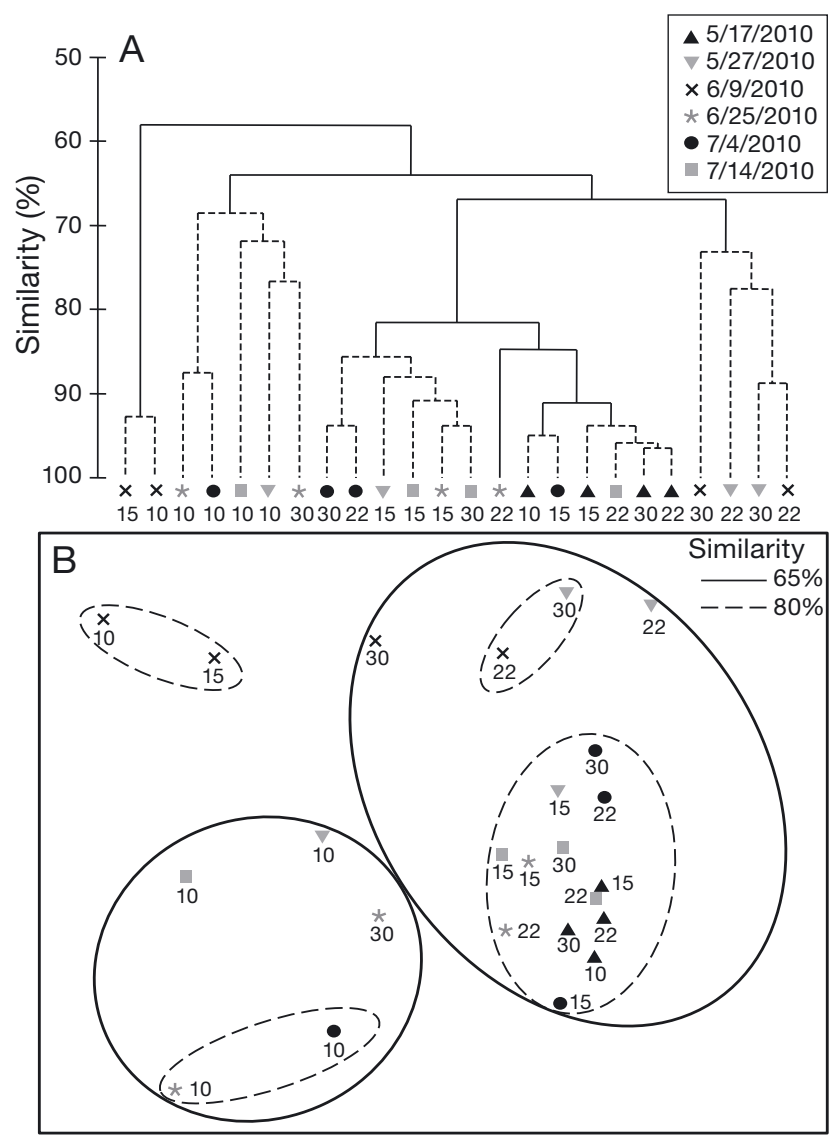

Fig. 8. (A) Hierarchical clustering dendrogram (using groupaverage linking) of assemblage composition from 24 samples taken over $6 \mathrm{~d}$ (indicated by symbols and legend entry) at 4 sampling stations across the coastal boundary layer (along the $10,15,22$, and $30 \mathrm{~m}$ isobaths, indicated by numbers adjacent to symbols), using standardized data. Solid black lines indicate significant group structure at the 5\% level. Dashed lines represent non-significant group structure. Sample station isobaths are reported beneath each symbol. (B) Non-metric multidimensional scaling plot (2D stress, 0.09 ; 3D stress, 0.06) from the 24 samples with superimposed significant clusters at similarity levels of $65 \%$ (solid lines) and $80 \%$ (dashed lines). Symbols and numbers as in (A)

the effect of date was driven by one particular sampling event on 9 June, when there was a distinct inner CBL assemblage (10 and $15 \mathrm{~m}$ stations; $92 \%$ similarity). The dendrogram from cluster analysis and the NMDS ordination showed 2 additional assemblages (Fig. 8): an inner CBL assemblage (68\% similarity) and a main CBL assemblage containing nearly all of the other samples from the CBL, the 2 outer CBL stations as well as the $15 \mathrm{~m}$ station ( $67 \%$ similarity).

The barnacles Balanus crenatus and B. nubilus larvae dominated the composition of the assemblage and drove differences between clusters. The assemblage at the inner CBL stations on 9 June (Fig. 8) was composed of $>75 \%$ B. crenatus cyprids. All other samples were composed of $30 \%$ or less B. crenatus cyprids. In addition, the 9 June inner CBL assemblage contained $<16 \%$ B. crenatus nauplii (early, middle, and late stage), compared to the assemblage from the majority of the CBL stations which was composed of 39 to $99 \%$ B. crenatus nauplii. The larger cluster of inner CBL assemblages also had low percentages of $B$. crenatus nauplii, ranging from 3 to $37 \%$, as well as a high proportion of $B$. nubilus cyprids, which ranged from 11 to $74 \%$, as opposed to the main CBL assemblage, which was composed of $<1$ to $10 \%$ B. nubilus cyprids. Crab larvae were in nearly all samples, but they did not generally make up a large percentage of the assemblage, except in the larger inner CBL cluster, which was composed of $21 \%$ crab larvae (compared to an average of $<0.1 \%$ crab larvae in the 9 June inner CBL assemblage and $4 \%$ crab larvae in the main CBL assemblage).

\section{DISCUSSION}

\section{Larval supply and retention within the CBL}

Consistent with previous work in this study region (Morgan et al. 2009b,c, Morgan \& Fisher 2010, Morgan et al. 2011, 2012), we found high abundances of benthic crustacean larvae in nearshore regions across sampling days under different oceanographic conditions. However, in contrast to previous work, we found a striking and persistent pattern of decreased larval abundance at locations closest to shore just outside the surf zone ( $<500 \mathrm{~m}$ from shore). While there were differences among taxa in cross-shore distributions of larvae, with barnacle abundance peaking at $850 \mathrm{~m}$ from shore and crab abundance highest $1100 \mathrm{~m}$ from shore, all benthic crustaceans were at their lowest abundance at the innermost station within the CBL (250 $\mathrm{m}$ from shore). We are unable to assess whether larvae were transported out of these innermost CBL waters (i.e. whether an intrusion of low larvae abundance waters was confined to this area), whether larvae were avoiding this region through active behavior, or whether an appreciable fraction of larvae were settling rapidly or being eaten and therefore exiting the plankton. Although we did not sample during strong southward currents, the consistency of low larval abundance across sampling days and oceanographic conditions suggests that larvae avoid the innermost waters in the CBL regardless of background transport conditions. These patterns are similar to that measured in southern California, a region of weak upwelling. Tapia \& Pine- 
da (2007) measured larval concentrations of Balanus glandula and Chthamalus spp. at 3 cross-shore stations within $1100 \mathrm{~m}$ from shore over a period of $7 \mathrm{~d}$. While concentrations of most larval stages of B. glandula were similar among stations, concentrations of third through sixth stage Chthamalus nauplii were lower at the innermost station, $300 \mathrm{~m}$ from shore (Tapia \& Pineda 2007). Even over a short temporal period, barnacle concentrations exhibited spatial structure and nauplii may potentially have avoided very nearshore waters.

Despite low concentrations of larvae in the innermost waters of the CBL, the high concentrations of all larval stages of barnacles in the CBL along the 15, 22, and $30 \mathrm{~m}$ isobaths suggest that many barnacle larvae may be retained within the CBL and develop in waters within $1100 \mathrm{~m}$ from shore. All larval stages of crabs occurred at the 2 outer CBL stations, suggesting that they may also complete development within the CBL. These findings are consistent with other studies in both weak and strong upwelling regions where high abundances of all larval stages occurred within a few kilometers from shore (Tapia \& Pineda 2007, Morgan et al. 2009b,c, Shanks \& Shearman 2009, Morgan \& Fisher 2010, Morgan et al. 2011, 2012). Benthic crustacean larvae exhibit depth preferences that can aid nearshore retention for most species in upwelling regions (Miller \& Morgan 2013). By remaining near the bottom, larvae can take advantage of slower velocities in the bottom boundary layer (in both the along- and cross-shore directions), as well as avoid offshore transport in the surface Ekman layer (Morgan et al. 2009b, Shanks \& Shearman 2009, Morgan \& Fisher 2010, Morgan et al. 2012).

\section{Inshore and offshore assemblages within the CBL}

A distinct larval assemblage occurred closest to shore within the CBL. Although some features of larval assemblages changed with time, these assemblages were predominantly defined by space: not only was there spatial structure in larval abundance, there was spatial structure in the composition of the assemblage. This spatial structure occurred even though physical conditions were variable among sampling dates (flow velocity, water temperature, stratification) and on many days there was no clear difference in physical parameters between the innermost station and those within the rest of the CBL (Figs. 2 \& 3).

The spatial boundary between assemblages of inner and outer stations within the CBL is dynamic.
Larval assemblages on half of the sampling dates at the $15 \mathrm{~m}$ station were most similar to the $10 \mathrm{~m}$ station, and on the other half were more similar to the $22 \mathrm{~m}$ station. There is no clear physical difference between these groupings of days apparent from our data, as they spanned oceanographic conditions. For example, on 9 June, 4 July, and 14 July the $15 \mathrm{~m}$ station matched most closely with the $10 \mathrm{~m}$ station, yet the water column profiles from each of these days are quite distinct (Fig. 3C-E). One possible physical factor we did not explore that could influence the demarcation of the inshore community is the width of the surf zone and associated rip current zone, which is itself a dynamic boundary, dependent on the significant wave height and tidal elevation (Lentz et al. 1999, Brown et al. 2009). Surf zone characteristics appear to impact shoreline settlement of invertebrates, with low settlement observed at reflective beaches - which are characterized by high beach slopes and standing waves and are thought to have reduced cross-shore exchange (Shanks et al. 2010). Rocky shores are hypothesized to be similar to reflective beaches, and if so, the associated reduction in cross-shore exchange might explain low settlement at some locations and low abundances of larvae in surf zone waters (Shanks et al. 2010). Our study found low larval concentrations in waters just beyond the surf zone, but at distances that could be influenced by surf zone processes through the action of rip currents. Specifically, off Horseshoe Cove (Fig. 1, just downcoast of station locations), wave-driven circulation has been observed to extend as a macro-rip up to distances $\sim 250 \mathrm{~m}$ offshore (J. L. Largier, unpubl. drifter data), comparable with the distance to our inner CBL station along the $10 \mathrm{~m}$ isobath. This suggests that the influence of wave-driven processes on larval transport may extend offshore (contrary to the idea of reduced exchange off rocky shores, as suggested by Shanks et al. 2010).

In addition to potential physical differences between the habitat of the inshore and offshore assemblages, predation may be higher within the narrow band of inner CBL water than farther offshore. Habitat along the $10 \mathrm{~m}$ isobath at our study site features rocky substrate with some areas supporting stands of the bull kelp, Nereocystis luetkeana. In central California, larval abundances were found to be negatively correlated with kelp density, and lower larval abundances on the inshore edges of kelp forests were attributed to predation (Gaines \& Roughgarden 1987). Although the kelp in our region is much more sparse than the giant kelp Macrocystis pyrifera beds in central California, predation is still a 
possible explanation for decreased abundance at the most inshore station of our study.

\section{Implications of cross-shelf larval structure within the $\mathrm{CBL}$}

Larvae are clearly spending time within the coastal boundary layer; some may even complete their entire development within the $\mathrm{CBL}$, which could impact estimates of population connectivity. During their time in the CBL, larvae are exposed to slower moving alongshore flows than farther offshore, which will have an impact on overall dispersal distance (Nickols et al. 2012, Nickols et al. unpubl. data). Although we did not have current velocity measurements throughout the water column beyond the $22 \mathrm{~m}$ isobath, concurrent measurements of surface currents by highfrequency radar showed that current velocities were faster farther offshore (data not shown). The radar domain begins $2 \mathrm{~km}$ offshore, and generally has high agreement with measurements from ADCPs (Kaplan et al. 2005). This gradient is also observed in a crossshore array of moorings deployed during WEST (Wind Events and Shelf Transport; Largier et al. 2006) and in other unpublished data from BML. Estimates of dispersal distance in this region should therefore consider current velocities within $1 \mathrm{~km}$ or less from shore, as this is where the majority of larvae appear to be concentrated. Such consideration may improve estimates of dispersal distance derived from pelagic larval durations, which are often larger than dispersal distances estimated from genetics, tagging, and natural tracers (Palumbi 2004, Jones et al. 2009, Shanks 2009, López-Duarte et al. 2012). Refining our understanding of dispersal distances will improve our ability to accurately model population dynamics and assess population persistence (Botsford et al. 2009, White et al. 2010, Burgess et al. in press).

The coast of northern California generally has lower recruitment than other regions along the west coast of North America (Connolly et al. 2001), and a longstanding question has been whether or not this pattern is linked to larval supply. Although it was proposed that larval supply is diminished when larvae are forced offshore by strong upwelling (e.g. Roughgarden et al. 1988), numerous studies now suggest strongly that many larvae of multiple species are retained nearshore during both upwelling and relaxation conditions (Tapia \& Pineda 2007, Morgan et al. 2009b,c, Shanks \& Shearman 2009, Morgan \& Fisher 2010, Morgan et al. 2011). Our study also found high abundance of larvae close to the shore, and extended closer to shore than previous work in this region of strong upwelling.

An important finding of our study is the observation of low larval concentrations and a different larval assemblage in the innermost waters of the CBL, indicating a potential disconnect between high larval abundance in the CBL and larval supply to shoreline recruitment habitat. Further, this disconnect appears to occur in waters beyond the surf zone, in contrast to recent work by Shanks et al. (2010) that suggests that surf zone processes may disrupt the supply of nearshore planktonic larvae to shoreline habitats. While these results are from a single location, they represent a diversity of oceanographic conditions and the observed mismatch raises important questions about how general this result may be. Our study also focuses attention on the need to understand the mechanisms that control transport of larvae to shoreline habitats, while highlighting methodological concerns of studies that explore links between supply and settlement. As we endeavor to better understand the links between larval dispersal and population dynamics, it is essential that the nearshore zone be studied in greater detail and that we work to address the spatial pattern of recruitment limitation in coastal systems.

Acknowledgements. We thank J. Demmer, R. Fontana, and $\mathrm{N}$. Weidberg for assistance in the field as well as D. Dann, M. Robart, and J. Herum for help with deployments of oceanographic instrumentation. J. Fisher provided guidance and feedback. This work was funded by California Sea Grant (NA08AR4170669) and the National Science Foundation (OCE-0927196 and OCE-0927255). K.J.N. was also supported by a Bodega Marine Laboratory Graduate Student Fellowship.

\section{LITERATURE CITED}

> Bertness MD, Gaines SD, Stephens EG, Yund PO (1992) Components of recruitment in populations of the acorn barnacle Semibalanus balanoides (Linnaeus). J Exp Mar Biol Ecol 156:199-215

> Borges R, Ben-Hamadou R, Chícharo MA, Ré P, Gonçalves EJ (2007) Horizontal spatial and temporal distribution patterns of nearshore larval fish assemblages at a temperate rocky shore. Estuar Coast Shelf Sci 71:412-428

Botsford LW (2001) Physical influences on recruitment to California Current invertebrate populations on multiple scales. ICES J Mar Sci 58:1081-1091

Botsford LW, Moloney CL, Hastings A, Largier JL, Powell TM, Higgins K, Quinn JF (1994) The influence of spatially and temporally varying oceanographic conditions on meroplankton metapopulations. Deep-Sea Res II 41: 107-145

Botsford LW, White JW, Coffroth MA, Paris CB and others (2009) Connectivity and resilience of coral reef metapop- 
ulations in marine protected areas: matching empirical efforts to predictive needs. Coral Reefs 28:327-337

Brown J, MacMahan J, Reniers A, Thornton E (2009) Surf zone diffusivity on a rip-channeled beach. J Geophys Res 114:C11015, doi:10.1029/2008JC005158

Burgess SC, Nickols KJ, Griesemer CD, Barnett LAK and others (in press) Beyond connectivity: how empirical methods can quantify population persistence to improve marine protected area design. Ecol Appl

Clarke KR, Gorley RN (2006) PRIMER v6: User Manual/ Tutorial. PRIMER-E, Plymouth

> Connell JH (1985) The consequences of variation in initial settlement vs. post-settlement mortality in rocky intertidal communities. J Exp Mar Biol Ecol 93:11-45

> Connolly SR, Menge BA, Roughgarden J (2001) A latitudinal gradient in recruitment of intertidal invertebrates in the northeast Pacific Ocean. Ecology 82:1799-1813

- Cowen RK (1985) Large-scale pattern of recruitment by the labrid, Semicossyphus pulcher: causes and implications. J Mar Res 43:719-742

> Dudas SE, Rilov G, Tyburczy J, Menge BA (2009) Linking larval abundance, onshore supply and settlement using instantaneous versus integrated methods. Mar Ecol Prog Ser 387:81-95

> Farrell TM, Bracher D, Roughgarden J (1991) Cross-shelf transport causes recruitment to intertidal populations in central California. Limnol Oceanogr 36:279-288

$>$ Gaines SD, Bertness MD (1992) Dispersal of juveniles and variable recruitment in sessile marine species. Nature 360:579-580

> Gaines SD, Roughgarden J (1985) Larval settlement rate: a leading determinant of structure in an ecological community of the marine intertidal zone. Proc Natl Acad Sci USA 82:3707-3711

Gaines SD, Roughgarden J (1987) Fish in offshore kelp forests affect recruitment to intertidal barnacle populations. Science 235:479-481

> Gaines SD, Brown S, Roughgarden J (1985) Spatial variation in larval concentrations as a cause of spatial variation in settlement for the barnacle, Balanus glandula. Oecologia 67:267-272

Gaylord B, Gaines SD (2000) Temperature or transport? Range limits in marine species mediated solely by flow. Am Nat 155:769-789

Gaylord B, Reed DC, Raimondi PT, Washburn L, McLean SR (2002) A physically based model of macroalgal spore dispersal in the wave and current-dominated nearshore. Ecology 83:1239-1251

Gaylord B, Reed DC, Washburn L, Raimondi PT (2004) Physical-biological coupling in spore dispersal of kelp forest macroalage. J Mar Syst 49:19-39

Gaylord B, Reed DC, Raimondi PT, Wasburn L (2006) Macroalgal spore dispersal in coastal environments: mechanistic insights revealed by theory and experiment. Ecol Monogr 76:481-502

> Gaylord B, Rosman JH, Reed DC, Koseff JR and others (2007) Spatial patterns of flow and their modification within and around a giant kelp forest. Limnol Oceanogr 52:1838-1852

> Gaylord B, Nickols KJ, Jurgens L (2012) Roles of transport and mixing processes in kelp forest ecology. J Exp Biol 215:997-1007

Graham WM, Largier JL (1997) Upwelling shadows as nearshore retention sites: the example of northern Monterey Bay. Cont Shelf Res 17:509-532
Jones GP, Almany GR, Russ GR, Sale PF, Steneck RS, van Oppen MJH, Willis BL (2009) Larval retention and connectivity among populations of corals and reef fishes: history, advances and challenges. Coral Reefs 28:307-325

> Kaplan DM, Largier JL (2006) HF radar-derived origin and surface waters off Bodega Bay, California. Deep-Sea Res II 53:2906-2930

Kaplan DM, Largier JL, Botsford LW (2005) HF radar observations of surface circulation off Bodega Bay (northern California, USA). J Geophys Res 110:C10020, doi:10. 1029/2005JC002959

> Largier JL (2003) Considerations in estimating larval dispersal distances from oceanographic data. Ecol Appl 13: S71-S89

- Largier JL, Magnell BA, Winant CD (1993) Subtidal circulation over the Northern California shelf. J Geophys Res 98:18147-18179

- Largier JL, Lawrence CA, Roughan M, Kaplan DM and others (2006) WEST: a northern Califrnia study of the role of wind-driven transport in the productivity of coastal plankton communities. Deep-Sea Res II 53:2833-2849

> Lentz SJ, Guza RT, Elgar S, Feddersen F, Herbers THC (1999) Momentum balances on the North Carolina inner shelf. J Geophys Res 104:18205-18226

> Levin LA (2006) Recent progress in understanding larval dispersal: new directions and digressions. Integr Comp Biol 46:282-297

> López-Duarte PC, Carson HS, Cook GS, Fodrie FJ, Becker BJ, DiBacco C, Levin LA (2012) What controls connectivity? An empirical, multi-species approach. Integr Comp Biol 52:511-524

- Mace AJ, Morgan SG (2006) Larval accumulation in the lee of a small headland: implications for the design of marine reserves. Mar Ecol Prog Ser 318:19-29

MacMahan J, Brown J, Brown J, Thornton E and others (2010) Mean Lagrangian flow behavior on an open coast rip-channeled beach: a new perspective. Mar Geol 268: $1-15$

McCulloch A, Shanks AL (2003) Topographically generated fronts, very nearshore oceanography and the distribution and settlement of mussel larvae and barnacle cyprids. J Plankton Res 25:1427-1439

> McPhee-Shaw EE, Nielsen KJ, Largier JL, Menge BA (2011) Nearshore chlorophyll-a events and wave-driven transport. Geophys Res Lett 38:1-5

> McQuaid CD, Phillips TE (2000) Limited wind-driven dispersal of intertidal mussel larvae: in situ evidence from the plankton and the spread of the invasive species Mytilus galloprovincialis in South Africa. Mar Ecol Prog Ser 201:211-220

> Menge BA, Blanchette C, Raimondi P, Freidenburg T and others (2004) Species interaction strength: testing model predictions along an upwelling gradient. Ecol Monogr 74:663-684

> Miller SH, Morgan SG (2013) Interspecific differences in depth preference: regulation of larval transport in an upwelling system. Mar Ecol Prog Ser 476:301-306

> Monismith SG (2004) A note on the potential transport of scalars and organisms by surface waters. Limnol Oceanogr 49:1214-1217

Morgan SG (2001) The larval ecology of marine communities. In: Bertness MD, Gaines SD, Hay ME (eds) Marine community ecology. Sinauer, Sunderland, MA

Morgan SG, Fisher JL (2010) Larval behavior regulates nearshore retention and offshore migration in an up- 
welling shadow and along the open coast. Mar Ecol Prog Ser 404:109-126

Morgan SG, Fisher JL, Mace AJ (2009a) Larval recruitment in a region of strong, persistent upwelling and recruitment limitation. Mar Ecol Prog Ser 394:79-99

Morgan SG, Fisher JL, Miller SH, McAfee ST, Largier JL (2009b) Nearshore larval retention in a region of strong upwelling and recruitment limitation. Ecology 90: 3489-3502

> Morgan SG, Fisher JL, Mace AJ, Akins L, Slaughter AM, Bollens SM (2009c) Cross-shelf distributions and recruitment of crab postlarvae in a region of strong upwelling. Mar Ecol Prog Ser 380:173-185

Morgan SG, Fisher JL, Largier JL (2011) Larval retention, entrainment and accumulation in the lee of a small headland: recruitment hotspots along windy coasts. Limnol Oceanogr 56:161-178

> Morgan SG, Fisher JL, McAfee ST, Largier JL, Halle CM (2012) Limited recruitment during relaxation events: larval advection and behavior in an upwelling system. Limnol Oceanogr 57:457-470

- Nickols KJ, Gaylord B, Largier JL (2012) The coastal boundary layer: predictable current structure decreases alongshore transport and alters scales of dispersal. Mar Ecol Prog Ser 464:17-35

Palumbi SR (2004) Marine reserves and ocean neighborhoods: the spatial scale of marine populations and their management. Annu Rev Environ Resour 29:31-68

Prairie JC, Sutherland KR, Nickols KJ, Kaltenberg AM (2012) Biophysical interactions in the plankton: a crossscale review. Limnol Oceanogr Fluids Environ 2: 121-145

Reed DC, Laur DR, Ebeling AW (1988) Variation in algal dispersal and recruitment: the importance of episodic events. Ecol Monogr 58:321-335

Reed DC, Kinlan BP, Raimondi PT, Washburn L, Gaylord B, Drake PT (2006) A metapopulation perspective on patch dynamics and connectivity of giant kelp. In: Kritzer JP, Sale PF (eds) Marine metapopulations. Academic Press, San Diego, CA

Rilov G, Dudas SE, Menge BA, Grantham BA, Lubchenco J, Schiel DR (2008) The surf zone: a semi-permeable barrier to onshore recruitment of invertebrate larvae? J Exp Mar Biol Ecol 361:59-74

Rosenfeld LK (1983) CODE-2: Moored array and large-scale data report. WHOI Technical Report 85-35:1-242

Roughan M, Mace AJ, Largier JL, Morgan SG, Fisher JL, Carter ML (2005) Subsurface recirculation and larval retention in the lee of a small headland: a variation on the upwelling shadow theme. J Geophys Res 110:C10027, doi:10.1029/2005JC002898

Roughgarden J, Gaines SD, Possingham H (1988) Recruitment dynamics in complex life-cycles. Science 241: 1460-1466

Send U, Beardsley RC, Winant CD (1987) Relaxation from upwelling in the Coastal Ocean Dynamics Experiment. J Geophys Res 92:1683-1698

Shanks AL (2009) Pelagic larval duration and dispersal dis-

Editorial responsibility: Lisandro Benedetti-Cecchi, Pisa, Italy tance revisited. Biol Bull 216:373-385

> Shanks AL, Eckert GL (2005) Population persistence of California Current fishes and benthic crustaceans: a marine drift paradox. Ecol Monogr 75:505-524

> Shanks AL, Shearman RK (2009) Paradigm lost? Cross-shelf distributions of intertidal invertebrate larvae are unaffected by upwelling or downwelling. Mar Ecol Prog Ser 385:189-204

> Shanks AL, Morgan SG, MacMahan J, Reniers AJHM (2010) Surf zone physical and morphological regime as determinants of temporal and spatial variation in larval recruitment. J Exp Mar Biol Ecol 392:140-150

Strathmann MF (1987) Reproduction and development of marine invertebrates of the northern Pacific Coast. University of Washington Press, Seattle, WA

Swearer SE, Shima JS, Hellberg ME, Thorrold SR and others (2002) Evidence of self-recruitment in demersal marine populations. Bull Mar Sci 70:S251-S271

Tapia FJ, Pineda J (2007) Stage-specific distribution of barnacle larvae in nearshore waters: potential for limited dispersal and high mortality rates. Mar Ecol Prog Ser 342:177-190

Thorson G (1946) Reproduction and larval development of Danish marine bottom invertebrates. Meddelelser fra Kommissionen for Hovundersoegelser Serie Plankton 4: $1-523$

Underwood AJ, Fairweather PG (1989) Supply-side ecology and benthic marine assemblages. Trends Ecol Evol 4: $16-20$

Underwood AJ, Keough MJ (2001) Supply-side ecology: the nature and consequences of variations in recruitment of intertidal organisms. In: Bertness MD, Gaines SD, Hay ME (eds) Marine community ecology. Sinauer, Sunderland, MA

> White JW, Botsford LW, Hastings A, Largier JL (2010) Population persistence in marine reserve networks: incorporating spatial heterogeneities in larval dispersal. Mar Ecol Prog Ser 398:49-67

Winant CD, Beardsley RC, Davis RE (1987) Moored wind, temperature, and current observations made during Coastal Ocean Dynamics Experiments 1 and 2 over the Northern California continental shelf and upper slope. J Geophys Res 92:1569-1604

Wing SR, Botsford LW, Largier JL, Morgan LE (1995a) Spatial structure of relaxation events and crab settlement in the northern California upwelling system. Mar Ecol Prog Ser 128:199-211

> Wing SR, Largier JL, Botsford LW, Quinn JF (1995b) Settlement and transport of benthic invertebrates in an intermittent upwelling region. Limnol Oceanogr 40: 316-329

Wing SR, Botsford LW, Ralston SV, Largier JL (1998) Meroplanktonic distribution and circulation in a coastal retention zone of the northern California upwelling system. Limnol Oceanogr 43:1710-1721

> Yoshioka PM (1982) Role of planktonic and benthic factors in the population dynamics of the bryozoan Membranipora membranacea. Ecology 63:457-468

Submitted: March 28, 2013; Accepted: September 20, 2013 Proofs received from author(s): November 14, 2013 